九州大学学術情報リポジトリ

Kyushu University Institutional Repository

\title{
Growth of Rhizopus Strains on Soybean and Their Protease Formation
}

Elegado, Francisco B. Laboratory of Food Technology, Faculty of Agriculture, Kyushu University

Fujio, Yusaku

Laboratory of Food Technology, Faculty of Agriculture, Kyushu University

https://doi.org/10.5109/24024

出版情報：九州大学大学院農学研究院紀要. 37 (3/4)，pp.315-324，1993-03. Kyushu University バージョン：

権利関係 : 


\title{
Growth of Rhizopus Strains on Soybean and Their Protease Formation
}

\author{
Francisco B. Elegado and Y usaku Fujio* \\ Laboratory of Food Technology, Faculty of Agriculture, \\ Kyushu University 46-09, Fukuoka 812, Japan
}

(Received November 30, 1992)

\begin{abstract}
Twenty six Rhizopus isolates were tested for their growth in raw soybean and a possible link between raw soybean growth and extracellular enzyme production was sought. The degree of growth was found to be proportional to enzyme production, particularly proteases, pectinases and carbohydrases. The various isolates were also screened for neutral proteolytic activities in solid cultures using raw and steamed soybean and in submerged culture using nutrient supplemented soybean powder.
\end{abstract}

\section{INTRODUCTION}

Rhizopus sps. are industrially important microorganism not only for its use in making fermented food products, such as tempeh from soybean, but also for its production of enzymes such as glucoamylase and protease. Although most of the food and enzyme industries are already using efficient strains, screening for better isolates has been a continuous activity in order to attain higher productivity, save processing energy and improve product quality.

Tempeh, a nutritionally rich fermented food native of Indonesia, has recently gained much worldwide attention because of the increasing demand of food protein to cope-up with the population explosion specially in less developed countries. Even in developed countries, vegetable-based proteins are recently gaining much preference because they are considered more healthful compared to animal derived protein. Its increasing popularity and relevance can be seen from the considerable research efforts made and are presently being done on this particular fermentation product. An excellent review on the recent developments in tempeh research was presented by Nout and Rombouts (1990).

The tempeh-making process, however, is considered to be quite wasteful in view of exhaustive water and heat treatment of the soybean in order to remove the undesirable factors such as off-flavour components, enzyme inhibitors and anti-nutritional compounds and to render it more susceptible to fungal growth by textural degradation and partial elimination of contaminating microorganisms. A total solid loss of at least $25 \%$ occurs mainly due to the dehulling, soaking and cooking process (Steinkraus, et al. 1983; Winarno, 1985). Some processes involving semi-dry technologies were proposed in order to reduce cooking period and provide higher tempeh yields by the reduction of losses (Steinkraus, 1985; Samish, 1987). Yet, the selection of particular strains to complement such processes are deemed as necessary specially in view of the fact that several fungal species involved in the traditional tempeh fermen-

* Corresponding author 
tation process are available (Samson, et al. 1987). Good growth in less treated soybean materials by selected Rhizopus strains coupled with higher formation of extra -cellular enzymes, particularly proteases, may mean greater resistance from these undesirable factors and could entail some considerable savings in pre-treatment water and processing energy.

It is mainly from the above premise that present investigative works involving the growth characteristics and protease production of several Rhizopus isolates were undertaken in this paper.

\section{MATERIALS AND METHODS}

\section{Microorganisms}

Twenty six Rhizopus isolates were used in this study. They were maintained on slants of potato dextrose agar (PDA) (Nissui Chemical Co., Japan), making fresh transfers at least every month. The isolates were first transferred to PDA slants and incubated at $30^{\circ} \mathrm{C}$ for 7 days before inoculation use.

\section{Soybean materials}

The soybean (yellow variety), a product of Ohio, USA, was purchased from a local distributor. The term 'raw soybean' mentioned in this report was prepared by $100 \%$ hydration upon overnight soaking in tap water or soaking in lactic acid solution ( $\mathrm{pH}$ 3) at $30^{\circ} \mathrm{C}$ for $3 \mathrm{~h}$ (Wang,et al., 1979), manually dehulled and washed with deionized water. The other soybean materials used were then termed according to the treatments done on 'raw soybean' namely: pasteurized, soaking at $70^{\circ} \mathrm{C}$ for $3 \mathrm{~h}$; boiled, boiling at deionized water for $30 \mathrm{~min}$; and sterilized, autoclaving for $20 \mathrm{~min}$. All soybean materials were drained thoroughly before use.

\section{Cultivation and degree of growth}

For growth screening in raw and steamed soybean, all isolates were inoculated in $10 \mathrm{~g}$ of the soybean materials placed in sterile petri plates covered with perforated vinyl material. The level of inoculum used were at a rate of $10^{7}$ spores per gram of substrate estimated from a previous spore counting experiment of the 7-day old slants of the available R hizopus isolates, i.e., the fungal slants were each added with $10 \mathrm{ml}$ sterile water and the level of spore suspension inoculated were specified from the previous estimate of the number of spores contained in each slant. The degree of growth in the various isolates were observed visually and recorded as plus or minuses at specific time intervals, decided from two independent observation trials.

\section{Cultural conditions for enzyme production}

There were three culture methods used in this experiment, namely: solid culture method, submerged culture method and tempeh-like fermentation method. For the solid culture method, $30 \mathrm{~g}$ of the soybean material was placed in $300 \mathrm{ml} \mathrm{E}$. flask covered with cotton plug and aluminum foil and then autoclaved at $121^{\circ} \mathrm{C}$ for $15 \mathrm{~min}$. After which, the Rhizopus strains were inoculated at a rate of about $10^{9} \mathrm{spores} / \mathrm{g}$ substrate and incubation was done at $30^{\circ} \mathrm{C}$ for 4 days. For the submerged culture method, $1.5 \%$ ground soybean (48 mesh) and $0.5 \%$ corn starch were added to $100 \mathrm{ml}$ of 
synthetic liquid medium consisting of $0.4 \% \mathrm{CH}_{3} \mathrm{COONH}_{4}, 0.1 \% \mathrm{~K}_{2} \mathrm{HPO}_{4}, 0.05 \% \mathrm{KCl}$, $0.05 \% \mathrm{MgSO}_{4} \cdot 7 \mathrm{H}_{2} \mathrm{O}, 0.001 \% \mathrm{FeSO}_{4} \cdot 7 \mathrm{H}_{2} \mathrm{O}$ and $0.001 \% \mathrm{ZnSo}_{4} \cdot 7 \mathrm{H}_{2} \mathrm{O}$ and the $\mathrm{pH}$ was adjusted to 5 using $\mathrm{CH}_{3} \mathrm{COOH}$. The mixture was placed in Sakaguchi flask covered with silicon plug and aluminum foil and then autoclaved at $121^{\circ} \mathrm{C}$ for $15 \mathrm{~min}$. A similar spore inoculation rate was employed and culture with shaking was done at 30" $\mathrm{C}$ for 4 days. For the tempeh-like fermentation process, the soybean material contained in vinyl packets (Steinkraus et al., 1983) were inoculated with spores at a similar rate as above and was mixed vigorously in order to facilitate good spore distribution on the substrate. To effect sufficient aeration, the vinyl packets were punctured with tiny perforations using a tiny pin. Incubation was done at $30^{\circ} \mathrm{C}$ for 24 h. All culture methods were carried out in two separate experiments, each tried in duplicate vessels, mixing the enzyme extracts into one.

\section{Preparation of enzyme solution}

Enzyme was extracted from both the solid and tempeh-like cultures by adding three folds of sterile phosphate buffer $(0.05 \mathrm{M}, \mathrm{pH} 7.0)$ to the basal medium and homogenization for $5 \mathrm{~min}$ in a Warring blender. The crushed mixture contained in an E. flask was added with 3 drops of toluene before placing in the cold room for overnight. In all three types of culture, the crude enzyme solution was obtained after centrifugation of the crushed mixture mentioned above or the 4 day-old submerged culture at $4^{\circ} \mathrm{C}$ for $20 \mathrm{~min}$ at $5,000 \mathrm{rpm}$ and vacuum filtration through a cellulose nitrate membrane filter $(0.3 \mu \mathrm{m})$.

\section{Determination of protease activity and other enzyme properties}

The crude enzyme extracts were assayed for proteolytic activity using Hammerstein casein as substrate based on a modified method of that described by Tobe et al. (1975). A mixture of $0.5 \mathrm{ml}$ crude enzyme, $0.75 \mathrm{ml}$ buffer ( $\mathrm{pH} 7.0,0.05 \mathrm{M}$ phosphate buffer) and $0.75 \mathrm{ml}$ of casein solution $(2.66 \mathrm{~g}$ in $0.1 \mathrm{~N} \mathrm{NaOH}, \mathrm{pH} 7.1)$ was incubated at $40^{\circ} \mathrm{C}$ for $20 \mathrm{~min}$ and the reaction was stopped by the addition of $2.0 \mathrm{ml}$ of $0.44 \mathrm{M}$ trichloroacetic acid. After removal of the undigested casein by filtration, the acid soluble products were determined spectrophotometrically at $280 \mathrm{~nm}$. The enzyme activity is defined as the amount of enzyme which changed the reading at $280 \mathrm{~nm}$, equivalent to $1 \mu \mathrm{g}$ tyrosine per min at $40^{\circ} \mathrm{C}$.

Other enzyme activities were also assayed as they could play important roles in the fungal growth involving less treated substrate materials. One unit of the pectolytic activity was defined as $1 \mu$ mole reducing sugar (in the form of alphagalacturonic acid) released per min from a reaction mixture consisting of $0.5 \mathrm{ml}$ crude enzyme, $1.0 \mathrm{ml}$ of $2 \%$ pectic acid solution and $1.0 \mathrm{ml}$ of phosphate buffer $(0.05 \mathrm{M}, \mathrm{pH}$ 6.5 ), incubated at $40^{\circ} \mathrm{C}$. The celluloytic activity unit was defined as $1 \mu$ mole reducing sugar (expressed as glucose) released per min from a reaction mixture consisting of 0 . $5 \mathrm{ml}$ crude enzyme, $1.0 \mathrm{ml}$ of $2 \%$ carboxymethylcellulose solution and $1.0 \mathrm{ml}$ of citrate buffer $(0.05 \mathrm{M}, \mathrm{pH} 5.5)$, incubated at $40^{\circ} \mathrm{C}$. The glucanase activity unit was defined as $1 \mu$ mole reducing sugar (expressed as glucose) released per min from a reaction mixture consisting of $0.5 \mathrm{ml}$ crude enzyme, $1.0 \mathrm{ml}$ of $2 \%$ soluble starch solution and 1 . $0 \mathrm{ml}$ acetate buffer $(0.05 \mathrm{M}, \mathrm{pH} 4.5)$, incubated at $40^{\circ} \mathrm{C}$. The reducing sugar was determined colorimetrically in $550 \mathrm{~nm}$ spectrophotometric reading based on the 
dinitrosalicylic acid (DNS) sugar assay method (Miller, 1959).

\section{RESULTS AND DISCUSSION}

\section{Degree of Rhizopus growth}

Table 1 shows the time course of the degree of growth of Rhizopus strains in raw and steamed soybean materials. Visual observation was found as adequate for our purpose since quantitative determination of growth on raw soybean using several methods reported in the literatures (Steinkraus et al., 1983; Swift, 1973; Blakeman, et

Table 1. Growth behaviour of Rhizopus strains in raw and steamed soybean substrate*.

\begin{tabular}{|c|c|c|c|c|c|c|c|c|c|c|}
\hline \multirow[t]{3}{*}{ STRAIN } & \multicolumn{10}{|c|}{ DEGREE OF GROWTH } \\
\hline & \multicolumn{5}{|c|}{ RAW SOYBEAN } & \multicolumn{5}{|c|}{ STEAMED SOYBEAN } \\
\hline & $12 \mathrm{~h}$ & $16 \mathrm{~h}$ & $20 \mathrm{~h}$ & $24 \mathrm{~h}$ & $36 \mathrm{~h}$ & $12 \mathrm{~h}$ & $16 \mathrm{~h}$ & $20 \mathrm{~h}$ & $24 \mathrm{~h}$ & $36 \mathrm{~h}$ \\
\hline F87 & - & $\operatorname{Tr}$ & ++ & ++ & +++ & $\operatorname{Tr}$ & + & ++ & +++ & ++++ \\
\hline IF05442 & - & $\operatorname{Tr}$ & + & ++ & +++ & $\operatorname{Tr}$ & + & ++ & +++ & $++t+$ \\
\hline QM186F & - & $\operatorname{Tr}$ & + & ++ & +++ & $\operatorname{Tr}$ & + & ++ & +++ & ++++ \\
\hline F98 & - & $\operatorname{Tr}$ & + & ++ & $++t$ & - & + & ++ & +++ & $++t+$ \\
\hline G82 & - & $\operatorname{Tr}$ & + & + & +++ & $\operatorname{Tr}$ & + & ++ & +++ & ++++ \\
\hline F94 & - & $\mathrm{Tr}$ & + & + & +++ & - & + & ++ & $++t$ & ++++ \\
\hline F76 & - & $\operatorname{Tr}$ & + & + & +++ & - & + & ++ & +++ & +++ \\
\hline F70 & - & $\operatorname{Tr}$ & + & + & +++ & - & + & ++ & ++ & +++ \\
\hline $\mathrm{ON}$ & - & $\operatorname{Tr}$ & + & + & +++ & - & $\operatorname{Tr}$ & + & ++ & ++ \\
\hline G7 & - & - & + & ++ & ++ & - & + & ++ & +++ & ++++ \\
\hline IF05318 & - & $\operatorname{Tr}$ & + & + & ++ & - & + & ++ & +++ & ++++ \\
\hline WJ & - & - & $\operatorname{Tr}$ & + & +++ & - & - & $\mathrm{Tr}$ & ++ & +++ \\
\hline F60 & & - & + & + & ++ & $\operatorname{Tr}$ & + & ++ & +++ & ++++ \\
\hline F61 & & - & + & + & ++ & - & $\mathrm{Tr}$ & & +++ & ++ \\
\hline F68 & - & $\operatorname{Tr}$ & $\mathrm{Tr}$ & + & + & - & $\mathrm{Tr}$ & + & ++ & +++ \\
\hline G16 & - & $\operatorname{Tr}$ & $\mathrm{Tr}$ & + & + & $\operatorname{Tr}$ & + & ++ & +++ & +++ \\
\hline F77 & - & $\operatorname{Tr}$ & + & + & + & - & + & + & ++ & ++ \\
\hline LKN & & - & $\operatorname{Tr}$ & + & $+t$ & - & - & & ++ & +++ \\
\hline IF05441 & - & - & $\mathrm{Tr}$ & + & ++ & - & + & ++ & +++ & $+t+t$ \\
\hline F75 & & - & $\operatorname{Tr}$ & + & + & - & - & & ++ & ++++ \\
\hline Rh3 & - & - & $\mathrm{Tr}$ & $\mathrm{Tr}$ & + & - & + & ++ & +++ & ++++ \\
\hline F67 & & - & $\operatorname{Tr}$ & $\mathrm{Tr}$ & + & - & - & + & +++ & $t+t+$ \\
\hline F62 & & - & $\operatorname{Tr}$ & $\mathrm{Tr}$ & + & - & - & + & ++ & +++ \\
\hline UM & & & - & $\mathrm{Tr}$ & ++ & - & $\operatorname{Tr}$ & + & ++ & +++ \\
\hline A11 & -- & - & & $\mathrm{Tr}$ & + & - & - & $\mathrm{T}$ & ++ & ++ \\
\hline $\mathrm{CJ}$ & & & - & $\operatorname{Tr}$ & $\operatorname{Tr}$ & - & $\operatorname{Tr}$ & + & ++ & +++ \\
\hline
\end{tabular}

*soybean was pre-soaked in tap water for overnight $(15 \mathrm{~h})$ to effect natural acid fermentation.

- no visible growth

Tr trace of visible growth

+ scattered colonies

++ mycelial growth almost covered the surface

$+t+$ luxuriant growth covered the entire surface

++++ very heavy growth with initial spore formation 
al., 1988; Arima and Uozumi, 1967) were found to be inapplicable for raw soybean. The glucosamine method (Arima and Uozumi, 1967) yielded consistent results with steamed soybean but not with raw soybean (data not shown). The enzyme digestion method described by Steinkraus (1983) also seemed unable to completely digest the raw soybean material.

As indicated in Table 1, growth was faster and more profused in steamed substrate than in raw soybean. However, some strains, particularly strain F87, showed interestingly good growth performance in overnight-soaked raw soybean, exhibiting good mycelial growth as early as the $20 \mathrm{~h}$ of fermentation. A pool of selected good

Table 2. Growth behaviour of selected Rhizopus isolates in raw and pasteurized soybean substrate.

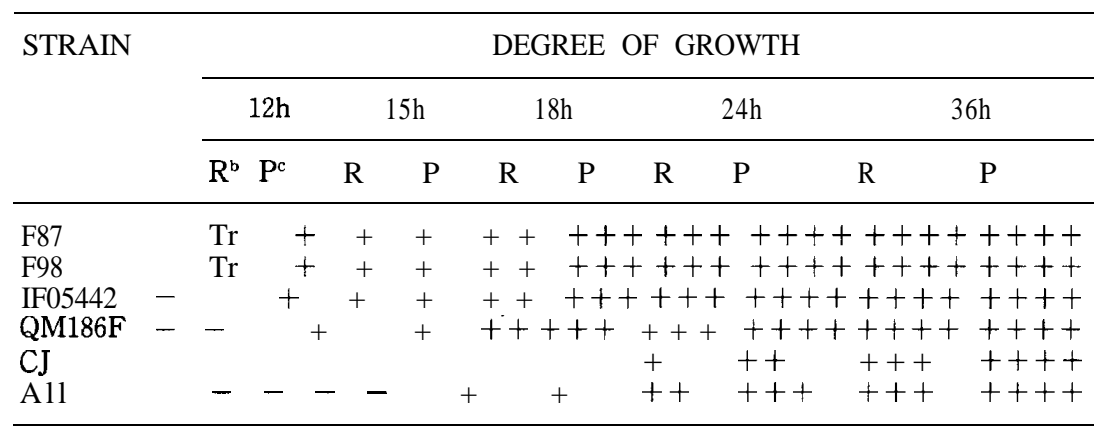

${ }^{\mathrm{a}}$ soybean was pre-soaked in lactic acid solution for $3 \mathrm{~h}$ at $30^{\circ} \mathrm{C}$.

bdehulled and drained raw soybean

cdehulled, pasteurized at $70^{\circ} \mathrm{C}$ for $30 \mathrm{~min}$ and drained.

Legend of symbols are the same as Table 1.

Table 3. Extracellular enzyme production of the best grower (F87) and the worst grower $(\mathrm{CJ})$ cultured in variously treated soybean substrate packed in vinyl material.

\begin{tabular}{|c|c|c|c|c|c|c|c|c|c|}
\hline \multirow{3}{*}{$\begin{array}{l}\text { SUBSTRATE } \\
\text { TREATMENT }\end{array}$} & \multirow{3}{*}{$\begin{array}{l}\text { CULTURE } \\
\text { TIME }\end{array}$} & \multicolumn{8}{|c|}{ ENZYME ACTIVITIES (U/ml)' } \\
\hline & & \multicolumn{4}{|c|}{ STRAIN F87 } & \multicolumn{4}{|c|}{ STRAIN CJ } \\
\hline & & $\mathbf{P}^{2}$ & $\mathrm{C}^{3} \quad \mathrm{G}^{4}$ & $\mathrm{PG}^{5}$ & & $\mathrm{P}$ & $\mathrm{C}$ & $\mathrm{G}$ & RG \\
\hline \multirow[t]{2}{*}{ RAW } & 16 & 0.02 & - & 9.28 & - & - & - & - & \\
\hline & 24 & 0.30 & 0.10 & 14.15 & - & - & - & - & \\
\hline \multirow[t]{2}{*}{ PASTEURIZED } & 16 & 2.50 & 0.06 & 7.08 & 0.28 & 0.09 & - & - & \\
\hline & 24 & 3.52 & 0.13 & 11.85 & 0.41 & 0.14 & - & - & \\
\hline \multirow[t]{2}{*}{ BOILED } & 16 & 1.71 & 0.31 & 6.29 & 0.12 & 0.08 & - & - & \\
\hline & 24 & 2.49 & 0.35 & 8.28 & 0.13 & 0.19 & - & - & \\
\hline \multirow[t]{2}{*}{ STERILIZED } & 16 & 0.84 & 0.19 & 5.28 & 0.17 & 0.07 & - & - & \\
\hline & 24 & 0.94 & 0.40 & 6.23 & 0.27 & 0.08 & 2.99 & - & \\
\hline
\end{tabular}

1 net values (minus the inherent enzyme activities of the uninoculated soybean material).

2 pectinase activity

${ }^{3}$ CMCase activity

4 Glucoamylase activity in soluble starch

${ }^{5}$ Glucoamylase activity in raw starch 
and worse growers were again tested for growth in raw and pasteurized soybean materials (this time soaked in lactic acid for $3 \mathrm{~h}$ ) and consistent results were obtained for raw soybean (Table 2). However, pasteurization resulted on a fair improvement on the growth of a poor grower in raw soybean (strain All). Such ability to grow in raw soybean may be suggestive of the capability of the fungus to resist from soybean inhibitors (Hesseltine et al., 1963) and bacterial competition by the production of more antibiotic substances and easier penetration of the texturally hard raw soybean by the production of more digestive enzymes. The relationship between growth and extracellular enzyme production was further focused in subsequent experiments.

\section{Formation of extra-cellular enzymes as related to growth and soybean treatment}

Table 3 shows the comparative formation of some extra-cellular enzymes in the best grower (F87) and the worst grower (CJ), inoculated in variously treated soybean materials which were fermented in a tempeh-like culture method. Enzyme production was shown to be directly proportional to growth ability as demonstrated by less pectolytic activity and basically nil glucoamylases in strain CJ. The production of raw starch glucoamylase and pectinase by F87 strain could have been induced in less treated soybean materials. However, lesser pectinase activity in raw soybean compared to pasteurized and boiled soybean materials, was also reflective of the inherent dependability of its production to mycelial growth, as previously cited by Charles and Gavin (see Steinkraus, 1983).

\section{R elationship of growth ability and soybean treatment on the proteolytic activity}

The protease production of two good growers (F87 and IFO 5442) and two poor growers (CJ and All) in raw soybean, growth in a tempeh-like fermentation method using variously treated soybean materials, are shown on Table 4. As in pectolytic activity, proteolytic activity was found to be both dependent on the mycelial growth and the inductive effect of less heat treatment of the soybean material, as shown by the highest production in pasteurized soybean by IFO 5442 isolate. The good growth of strain All in pasteurized soybean material also prompted it to produce higher proteolytic activity, unlike in raw soybean.

\section{Enzyme production by aseptic solid substrate method}

In tempeh making, bacteria are said to take part in the fermentation process and may also contribute to enzyme formation. In order to assess the formation of extra -cellular enzymes in purely inoculated substrates, aseptic culture method in steamed soybean was done using cotton-plugged E. flasks. Strain F87, the best grower in raw soybean and UQM 186F (Sukara and Doelle, 1989), a standard strain isolated from tempeh, were used. The time-courses of the production of protease, glucanase, pectinase and CMCase are shown in Fig. 1. For comparative purposes with the tempeh-like fermentation method, the enzyme activities were assayed up only to the $36 \mathrm{~h}$ of fermentation. Results showed that proteases and pectinases production starts at an earlier incubation time compared to glucanase and CMCases. Protease production in strain F87 was already at an stationary phase after the first day of fermentation unlike that of the protease production in strain UQM 186F. As glucanase and CMCase were late comers in the pool of enzymes produced by the fungal organism 
(being still on the exponential phase at the $36 \mathrm{~h}$ ), proteases and pectinases are then presumed to be more responsible in soybean substrate digestion. Compared with the results of tempeh-like method listed in Table 3 and 4 above, the enzymes produced in flask fermentation were slightly less, perhaps due to limited aeration, but these results are already suggestive that enzyme production in tempeh fermentation could be purely attributed to the fungal organism and that the enzymes secreted by bacteria present in tempeh is quite negligible.

\section{Protease production}

There has been a common understanding that proteases are one of the major enzymes in tempeh fermentation (Wang et al., 1974). Both neutral and acidic proteases were found to exist in soybean fermentation by Rhizopus sps. (Hesseltine et al., 1963; Wang, et al., 1974; Harayama and Yasuhira, 1987). Dealing with only the neutral proteases, the results of assays of proteolytic enzymes in both the solid cultures of raw and steamed soybean substrates and liquid culture using nutrient supplemented soybean powder are shown in Fig. 2. Results showed varying responses of the

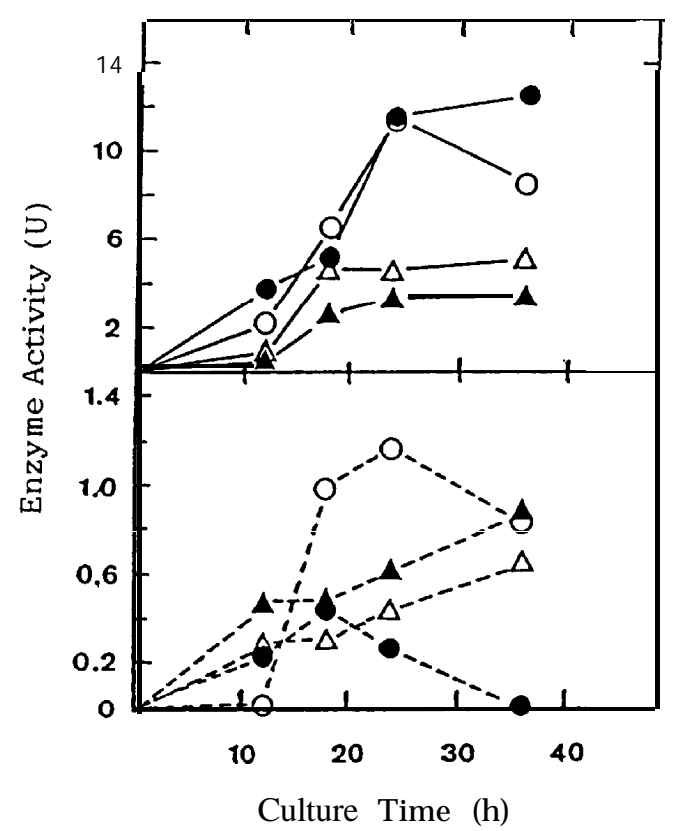

Fig. 1. Time course of the production of some extracellular enzymes in the crude extract from solid cultures of Rhizopus strains F87 and UQM 186F aseptically cultured.

Symbols: F87, open symbols; UQM 186F, closed symbols protease; circles with solid line glucanase; triangles with solid line pectinase; circles with broken line CMCase; triangles with broken line 


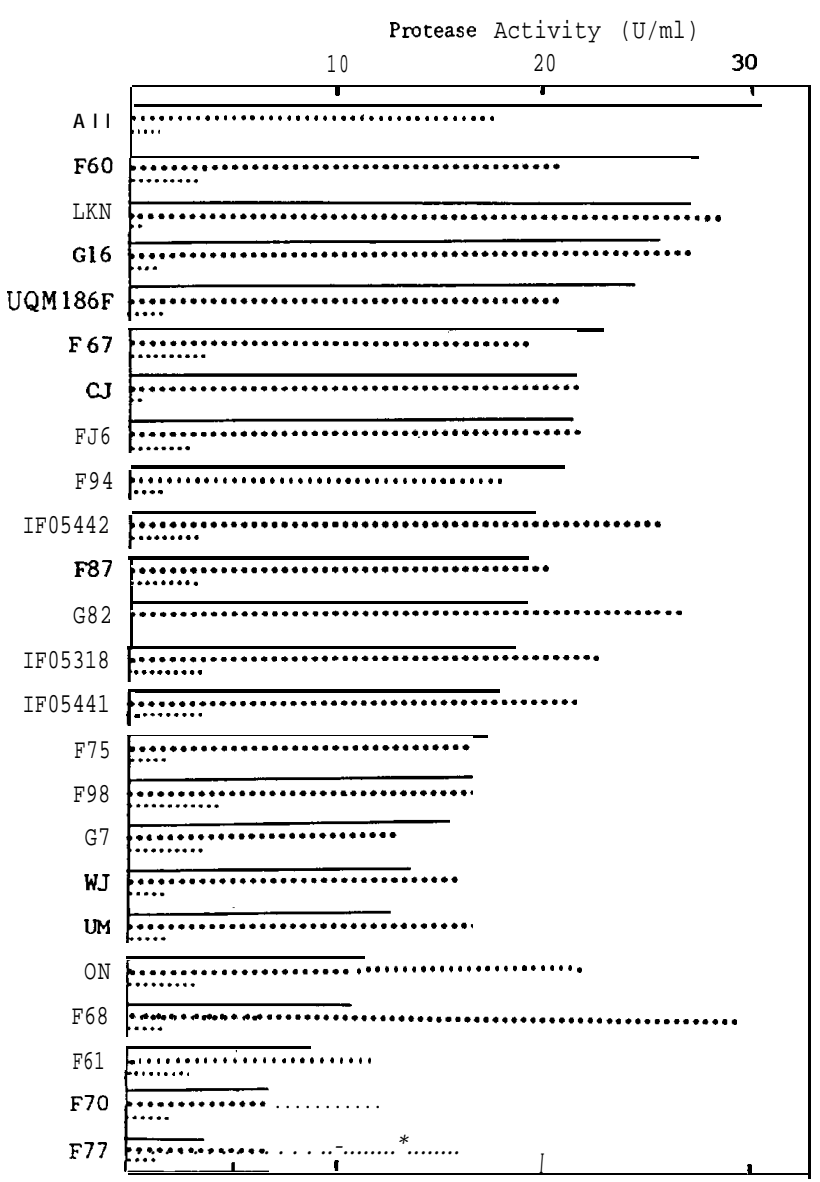

Fig. 2. Production of neutral proteases by several Rhizopus strains in solid culture. Symbols; solid line, solid culture on steamed soybean large dotted line, solid culture on raw soybean small dotted line, submerged culture

Table 4. Production of neutral proteases by selected isolates cultured in variously treated soybean substrates packed in perforated vinyl material.

\begin{tabular}{lcrrrr}
\hline \multirow{2}{*}{$\begin{array}{l}\text { SUBSTRATE } \\
\text { TREATMENT }\end{array}$} & CULTURE & \multicolumn{4}{c}{ PROTEASE ACTIVITY (U/ml) } \\
\cline { 3 - 6 } & TIME & F87 & IF05442 & CJ & A11 \\
\hline RAW & 16 & 8.29 & 14.37 & - & - \\
& 24 & 13.90 & 25.60 & - & \\
PASTEURIZED & 16 & 9.91 & 20.55 & 6.24 & 4.20 \\
& 24 & 16.43 & 33.35 & 12.85 & 29.14 \\
BOILED & 16 & 9.99 & 3.63 & 1.19 & 2.11 \\
& 24 & 15.21 & 12.36 & 6.86 & 25.02 \\
STERILIZED & 16 & 4.82 & 9.47 & 2.37 & 4.51 \\
& 24 & 19.41 & 20.34 & 17.22 & 24.97 \\
\hline
\end{tabular}


different Rhizopus isolates on the type of medium used. In the liquid culture method using nutrient supplemented soybean powder (Table 4), strains F98 and Rh3 produced the most amount of proteolytic enzymes while in solid culture of steamed soybean strains All and F60 showed the highest protease activities. Using raw soybean (u.v. irradiated before fungal inoculation to minimize bacterial contamination), considerable protease has also been produced (Table 4), quite comparable to that of steamed soybean. The highest protease producers in raw soybean after 4 days fermentation were strains F68 and F75. These strains may not be early enzyme producers as they were not able to show any noticeable fast growth in the first day of growth testing (Table 1) but in the long run they produced the highest protease activities in raw soybean, The above observations may be suggestive of the great complexity of the properties of the enzymes of fungal microorganisms, being so much sensitive to the physical and cultural conditions for growth and to their constant interactions. Rhizopus proteases are found to exist in multiple forms (Wang and Hesseltine, 1970) and mostly held responsible for the degradation of other enzymes resulting to multiplicity in forms and actions. It seems that constant evaluation of the protease component of an enzyme mixture in the screening of other desired enzymes, in the evaluation of the characteristic of the microorganism or any other purpose on hand may be helpful if not indispensable to help clarify matters. Future works on the screening for pectolytic activities of the $\mathbf{R}$ hizopus isolates are expected to be guided by these initial results.

\section{REFERENCES}

Arima, K. and T. Uozumi 1967 A new method for estimation of the mycelial weight in koji. Agricultural and Biological Chemistry. 31: 1, 119-123

Blakeman, J. P., A. R. McCracken and D. A. Seaby 1988 Changes brought about in solid substrates after fermentation of mixtures of cereals and pulses with Rhizopus oryzae. Journal of the Science in Food and Agriculture. 45, 109-118

Harayama, F. and H. Yasuhira 1987 Growth Characteristics of genus Rhizopus incubated on steamed soybeans. Journal of the Brewery Society of Japan (in Japanese). 82: 10, 607-702

Hesseltine, C. W., R. de Camargo and J. J. Rackis 1963 A mould inhibitor in soybeans. Nature. 200, 1226-1227

Miller, G. L. 1959 Use of dinitrosalicylic acid reagent for determination of reducing sugar. Analytical Chemistry. 39: 3, 426-428

Nout, M. J. R. and F. M. Rombouts 1990 A review: Recent developments in tempeh research. Journal of Applied Microbiology. 69, 60-633

Samish, S. 1987 An improved method for producing tempeh from soybean. Book of Abstracts, 7th World Congress of Food Science and Technology. Raffles City, Singapore: Singapore Institute of Food Science and Technology. p. 145

Samson, R. A., J. A. Van Kooiji and E. de Boer 1987 Microbiological quality of commercial tempeh in the Netherlands. Journal of Food Protection. 50, 92-94

Steinkraus, K. H., R. E. Cullen, C. S. Pederson, L. F. Nellis and B. K. Gavitt 1983 Indonesian tempe and related fermentations. In: Handbook of Indigenous Fermented Foods, ed. Steinkraus, K. H. et al., pp. 1-94. New York: Marcel Dekker

Steinkraus, K. H. 1985 Manufacture of tempe-tradition and modern. Proceedings, Asian Symposium on Non-salted Soybean Fermentation. Tsukuba, Japan, July 1985. pp. 9-19. Tsukuba Science City: National Food Research Institute 
Sukara, E. and H. W. Dolle 1989 A one-step process for the production of single-cell protein and amyloglucosidase. Applied Microbiology and Biotechnology. 30, 135-140

Swift, M. J. 1973 The estimation of mycelial biomass by determinaiton of the hexosamine content of wood tissue decayed by fungi. Soil Biological Biochemistry. 5, 321-332

Tobe, S., T. Takami, Y. Hirose and K. Mitsugi 1975 Agricultural and Biological Chemistry. 39, 1749

Wang, H. L. and C. W. Hesseltine 1970 Multiple forms of Rhizopusoligosporus protease. Archives of Biochemistry and Biophysics. 140, 459-463

Wang, H. L., J. B. Vespa and C. W. Hesseltine 1974 Acid protease production by fungi used in soybean food fermentation. Applied Microbiology. 27: 5, 906-911

Wang, H. L., E. W. Swan,C. W. Hesseltine and H. D. Heath 1979 Hydration of whole soybeans affects solids losses and cooking quality. Journal of Food Science. 44, 1510-1513

Winarno, F. G. 1985 Tempe making on various strates-including unconventional legumes. Proceedings, Asian Symposium on Non-salted Soybean Fermentation. Tsukuba, Japan, July 1985. pp. 125-141. Tsukuba Science City: National Food Research Institute 